\title{
A study of post-dated pregnancy with special reference to maternal and perinatal outcome in nulliparous women
}

\author{
Shreyasi Karmakar ${ }^{1 *}$, Sabyasachi Bid ${ }^{2}$, Tapan Kumar Maiti ${ }^{3}$
}

\begin{abstract}
${ }^{1}$ Department of Obstetrics and Gynaecology, ESI-PGIMSR, ESIC Medical College, Joka, Kolkata, West Bengal, India ${ }^{2}$ Department of Anesthesiology, ESI-PGIMSR, ESIC Medical College, Joka, Kolkata, West Bengal, India ${ }^{3}$ Department of Obstetrics and Gynecology, N.R.S. Medical College, Kolkata, West Bengal, India
\end{abstract}

Received: 28 August 2020

Accepted: 02 October 2020

\author{
*Correspondence: \\ Dr. Shreyasi Karmakar, \\ E-mail: drshreyasibid@gmail.com
}

Copyright: (c) the author(s), publisher and licensee Medip Academy. This is an open-access article distributed under the terms of the Creative Commons Attribution Non-Commercial License, which permits unrestricted non-commercial use, distribution, and reproduction in any medium, provided the original work is properly cited.

\begin{abstract}
Background: The study was aimed to determine the mode of delivery, maternal outcome and perinatal outcome in prolonged pregnancy.

Methods: It was a prospective observational study. Uncomplicated nulliparous singleton pregnancies who have completed 37 weeks of gestation were included in the study. Inclusion and exclusion criteria were strictly followed. Total 200 cases were divided into study group and control group. Those who have crossed their Estimated date of delivery (EDD) were compared with term pregnancies (not crossed their EDD).

Results: The study group and control group consist of 114 and 86 women respectively. The incidence of caesarean section $(64.04 \%)$, induction of labour $(50.88 \%)$ is significantly higher in the study group. It also shows that the occurrence of caesarean section $(63.79 \%)$ is more in post-dated pregnant women who underwent induction of labour. The most common indication for caesarean section was fetal distress in both groups. The commonest maternal complication was prolonged labour and perinatal complication was fetal distress in both groups. The incidence of low birth weight was significantly less in post-dated pregnancy.

Conclusions: Our study suggests that the incidence of induction of labour and caesarean section is significantly higher in post-dated pregnancy. Although the mean birth weight baby is more in them, a definite policy should be recommended for optimum timing of intervention to avoid maternal and perinatal complications.
\end{abstract}

Keywords: Post-dated pregnancy, Induction of labour, Caesarean section, Maternal complications, Perinatal complications

\section{INTRODUCTION}

The average duration of pregnancy is 280 days or 40 weeks after 1st day of last menstrual period. Post-dated pregnancy is defined by American college of obstetricians and gynecologists (ACOG) 2004 as a gestation longer than 40 weeks or 280 days from Last menstrual period (LMP). ${ }^{1}$ The commonest cause of post-dated pregnancy is an error in calculation of gestational age. Although the last menstrual period has been traditionally used to calculate the Expected date of delivery (EDD), many inaccuracies exist using this method in women who have irregular cycles, have been on recent hormonal birth control pill or who have first trimester bleeding.

Among the potential predisposing factors pre-pregnancy Body mass index BMI $(>25)$ and nulliparity are significantly associated with prolonged pregnancy. ${ }^{2}$ Nulliparous women who have long cervical length, that is, in third or fourth quartile, are twice likely to deliver after 42 weeks. $^{3}$ Sometimes prolonged pregnancies are genetically determined as some mothers have repeated prolonged pregnancy. It has been seen that sometimes the tendency of prolonged pregnancy is influenced genetically mainly by maternal gene. ${ }^{4-6}$ Some rare congenital causes 
like anencephaly, placental sulphatase deficiency have been traditionally associated with postdatism. An intact fetal pituitary adrenal axis appears to be necessary for initiation of labour pain. In same fashion women with placental sulphatase deficiency display a decreased ability to synthesize estrogen (E3 or estriol) through placenta and have a tendency to go post-term. It is a rare $\mathrm{x}$-linked recessive disorder.

Postdated pregnancy occurs in approximately 3-12\% pregnancies and carries increased risk to fetus and mother in almost all the studies reviewed. Although the incidence of fetal postmaturity syndrome is not conclusively determined at 42 or 43 weeks but data shows its incidence is around 10-20\% at 42 completed weeks (ACOG 2016 d). ${ }^{7}$ Features of postmature new-born are wrinkled, patchy, peeling skin; a long thin body often associated with opened eyes, unusual alertness, old and worried appearance. Associated oligohydramnios substantially raises the likelihood of postmaturity and fetal distress by umbilical cord compression. ${ }^{8}{ }^{8}$ Doppler studies have shown that renal blood flow is reduced in post term pregnancies which results in oligohydramnios ${ }^{10}$ Moreover, meconium release into an already reduced amniotic fluid volume results in thick, viscous meconium stained liquor that may lead to Meconium aspiration syndrome (MAS). Although the fetal growth velocity decreases after its peak at 37 weeks most of the fetuses continue to grow. As per Martin et al, the incidence of macrosomic baby is $11 \%$ in 42 weeks whereas it is only $8.2 \%$ in 37 to 41 weeks. ${ }^{11}$

Investigations have shown that cord blood erythropoietin levels are significantly higher in pregnancies of 41 weeks or more. ${ }^{12}$ This signifies that fetal oxygenation is decreased in some postdated pregnancies.

The maternal risks of postdated pregnancies are often under appreciated. These include increased incidence of labour dystocia (9-12\% versus $2-7 \%$ at term), severe perineal injury ( $3 \mathrm{rd}$ and 4 th degree perineal lacerations) related to macrosomia (3.3\% versus $2.6 \%$ at term), operative vaginal delivery and a doubling in the rate of caesarean delivery (14\% versus $7 \%$ at term). ${ }^{13-16}$ The later is associated with higher risk of complications such as endometritis, haemorrhage and thromboembolic disease. $^{15,17}$

Subsequent reviews have reinforced the utility of policy of routine induction of labour at 41 weeks to reduce caesarean section rate and perinatal mortality.

Society of obstetricians and gynaecologists of Canada (SOGC) recommends that after 41 weeks of gestation if the dates are certain, women should be offered elective delivery. ${ }^{18}$ Royal College of obstetricians and gynaecologists (RCOG) 2001 recommends that women with uncomplicated pregnancies should be offered induction of labour beyond 41 weeks. From 42 weeks, women who decline induction of labour should be offered increased antenatal monitoring, consisting of twice weekly
CTG and USG estimation of maximum amniotic pool depth. ${ }^{19}$

With this background present study was undertaken to analyse the outcome of pregnancies which crossed the expected date of delivery in nulliparous women.

\section{Objective of the study}

The objectives of the present study were as follows: to study the maternal outcome in postdated nulliparous pregnancy, to study the perinatal outcome in postdated nulliparous pregnancy and to compare maternal and perinatal outcome of postdated nulliparous pregnancy with term nulliparous pregnancy (which has not crossed EDD).

\section{METHODS}

This prospective observational study was conducted in the Department of Obstetrics and Gynaecology, I.P.G.M.E. and R./S.S.K.M. Hospital, Kolkata for 1 year duration. Total 200 patients were selected from maternity ward and labour room and divided into study and control group.

\section{Inclusion criteria}

The inclusion criteria for the study was as follows: nulliparous women, singleton pregnancy and gestational age $\geq 37$ weeks.

\section{Exclusion criteria}

The exclusion criteria for the study was as follows: congenital anomaly of fetus, polyhydramnios, eclampsia or preeclampsia, antepartum haemorrhage (APH), heart disease, elderly primi and medical disorders.

The patients are divided into two groups: study groupgestational age $>40$ weeks (number 114) and control group- gestational age 37-40 weeks (number 86 )

Complete assessment of postdated pregnancy was done including associated maternal conditions and complications. Fetal monitoring was done by Fetal heart rate (FHR) monitoring, daily Cardiotocography (CTG), Ultrasound (USG), doppler study and Daily fetal movement count (DFMC).

Labour was monitored closely in all the patients of study and control group. Maternal parameters like induction of labour, mode of delivery, prolonged labour, shoulder dystocia, retained placenta, rupture uterus and maternal mortality were studied. Among the neonatal parameters fetal distress, still-born, neonatal asphyxia, Low birth weight (LBW), meconium aspiration syndrome, morbidities due to instrumental deliveries, neonatal sepsis and neonatal death were recorded.

The study was approved by the institutional ethical committee. Consent of all the patient in the study and 
control group was taken. A proforma was formulated and filled for all the patients.

All the data were analysed, plotted and compared by using student's t test, chi-square test and Fischer's test as appropriate.

\section{RESULTS}

(Table 1) In the study group out of $114,30(26.32 \%)$ had normal vaginal delivery, $73(64.04 \%)$ had Lower uterine segment cesarean section (LUCS) and 11 (9.64\%) was delivered by instrumental deliveries. In the control group among 86, 45 (52.33\%) had normal vaginal delivery, 23 $(26.74 \%)$ delivered by LUCS and 18 (20.93\%) by instrumental delivery. $\mathrm{p}<0.05$ which is statistically significant.

Table 1: Comparison of mode of delivery in study and control group.

\begin{tabular}{|c|c|c|}
\hline \multirow{2}{*}{$\begin{array}{l}\text { Mode of } \\
\text { delivery }\end{array}$} & $\begin{array}{c}\text { Study } \\
(\mathrm{n}=114)\end{array}$ & Control $(\mathrm{n}=86)$ \\
\hline & $\mathbf{N}(\%)$ & $\mathbf{N}(\%)$ \\
\hline NVD & $30(26.32)$ & $45(52.33)$ \\
\hline $\begin{array}{l}\text { Instrumental } \\
\text { delivery }\end{array}$ & $11(9.64)$ & $18(20.93)$ \\
\hline LUCS & $73(64.04)$ & $23(26.74)$ \\
\hline
\end{tabular}

$\mathrm{p}$ value 0.000

Table 2: Comparison of induction of labour and spontaneous onset of labour in study versus control group.

\begin{tabular}{|c|c|c|}
\hline \multirow[t]{2}{*}{ Onset of labour } & $\begin{array}{l}\text { Study } \\
(n=114)\end{array}$ & Control $(n=86)$ \\
\hline & $\mathbf{N}(\%)$ & $\mathbf{N}(\%)$ \\
\hline $\begin{array}{l}\text { Induction of } \\
\text { labour }\end{array}$ & $58(50.88)$ & $10(11.63)$ \\
\hline $\begin{array}{l}\text { Spontaneous } \\
\text { onset of labour }\end{array}$ & $42(36.84)$ & $74(86.05)$ \\
\hline Elective LUCS & $14(12.28)$ & $2(2.32)$ \\
\hline
\end{tabular}

Table 3: Comparison of mode of delivery in induction of labour group in study versus control.

\begin{tabular}{|lll|}
\hline $\begin{array}{l}\text { Mode of } \\
\text { delivery }\end{array}$ & $\begin{array}{l}\text { Study }(\mathbf{n = 5 8}) \\
\mathbf{N}(\boldsymbol{\%})\end{array}$ & $\begin{array}{l}\text { Control } \\
(\mathbf{n}=\mathbf{1 0})\end{array}$ \\
\hline NVD & $15(25.86)$ & $6(60)$ \\
\hline $\begin{array}{l}\text { Instrumental } \\
\text { delivery }\end{array}$ & $6(10.35)$ & $1(10)$ \\
\hline LUCS & $37(63.79)$ & $3(30)$ \\
\hline
\end{tabular}

Table 2 shows onset of labour wise distribution of cases in study and control group. Among 114 patients $58(50.88 \%)$ have undergone induction of labour, 42 (36.84\%) had spontaneous onset of labour and 14 (12.28\%) were delivered by elective caesarean section in study group. On the other hand out of 86 in control group 10 (11.63\%), 74 $(86.05 \%)$ and $2(2.32 \%)$ had induction of labour, spontaneous onset of labour and elective caesarean section respectively. This difference is statistically significant $(\mathrm{p}<0.05)$.

Table 3 depicts that among 58 women in study group in whom labour induction was done only 15 (25.86\%) had normal delivery, $6(10.35 \%)$ had instrumental delivery and $37(63.79 \%)$ had caesarean section. Whereas in the control group among 10 induced labour patients $6(60 \%), 1(10 \%)$ and $3(30 \%)$ had normal delivery, instrumental delivery and caesarean section respectively. This difference is statistically significant $(\mathrm{p}<0.05)$.

Table 4: Comparison of mode of delivery in spontaneous onset of labour group in study versus control.

\begin{tabular}{|lll|}
\hline $\begin{array}{l}\text { Mode of } \\
\text { delivery }\end{array}$ & Study $(\mathrm{n}=42)$ & Control $(\mathrm{n}=74)$ \\
\hline NVD & $17(40.48 \%)$ & $41(55.41 \%)$ \\
\hline $\begin{array}{l}\text { Instrumental } \\
\text { delivery }\end{array}$ & $5(11.90 \%)$ & $17(22.97 \%)$ \\
\hline LUCS & $20(47.62 \%)$ & $16(21.62 \%)$ \\
\hline
\end{tabular}

Table 5: Comparison of indications of caesarean section in study versus control group.

\begin{tabular}{|llll|}
\hline $\begin{array}{l}\text { Indication of } \\
\text { LUCS }\end{array}$ & $\begin{array}{l}\text { Study } \\
(\mathbf{n = 7 3 )}\end{array}$ & $\begin{array}{l}\text { Control } \\
(\mathbf{n = 2 3})\end{array}$ & $\begin{array}{l}\mathbf{P} \\
\text { value }\end{array}$ \\
\hline Fetal distress & $26(35.61)$ & $\begin{array}{l}10 \\
\mathbf{N}(\mathbf{\%})\end{array}$ & 0.132 \\
\hline Oligohydramnios & $5(6.85)$ & $2(8.7)$ & 0.216 \\
\hline Induction failure & $15(20.55)$ & 0 & $\begin{array}{l}\text { Not } \\
\text { done }\end{array}$ \\
\hline NPOL & $12(16.44)$ & $3(13.04)$ & 0.070 \\
\hline $\begin{array}{l}\text { Thick meconium } \\
\text { stained liquor }\end{array}$ & $23(31.5)$ & $6(26.09)$ & 0.274 \\
\hline Elective LUCS & $14(19.17)$ & $2(8.7)$ & 0.019 \\
\hline
\end{tabular}

Table 6: Comparison of maternal complications in study versus control group.

\begin{tabular}{|c|c|c|c|}
\hline \multirow{2}{*}{$\begin{array}{l}\text { Maternal } \\
\text { complications }\end{array}$} & $\begin{array}{l}\text { Study } \\
(n=114)\end{array}$ & $\begin{array}{l}\text { Control } \\
(n=86)\end{array}$ & \multirow{2}{*}{ P value } \\
\hline & $\mathbf{N}(\%)$ & $\mathbf{N}(\%)$ & \\
\hline $\begin{array}{l}\text { Shoulder } \\
\text { dystocia }\end{array}$ & $4(3.51)$ & 0 & Not done \\
\hline $\begin{array}{l}\text { Prolonged } \\
\text { labour }\end{array}$ & $\begin{array}{l}14 \\
(12.28)\end{array}$ & $\begin{array}{l}14 \\
(16.28)\end{array}$ & 0.416 \\
\hline PPH & $9(7.89)$ & $3(3.49)$ & 0.293 \\
\hline Cervical tear & $2(1.75)$ & $3(3.49)$ & 0.203 \\
\hline
\end{tabular}

Table 4 shows that among the 42 postdated patients whose labour started spontaneously $17(40.48 \%)$ had normal 
delivery, $5(11.90 \%)$ had instrumental delivery and 20 $(47.625 \%)$ had caesarean section. These values were 41 $(55.41 \%), 17(22.97 \%)$ and $16(21.62 \%)$ respectively among 74 term nulliparous patients. These values are also statistically significant $(\mathrm{p}<0.05)$.

Table 7: Comparison of perinatal complications in study versus control group.

\begin{tabular}{|c|c|c|c|}
\hline $\begin{array}{l}\text { Fetal } \\
\text { complications }\end{array}$ & $\begin{array}{l}\text { Study } \\
(n=114)\end{array}$ & $\begin{array}{l}\text { Control } \\
(n=86)\end{array}$ & p-value \\
\hline Fetal distress & $\begin{array}{l}29 \\
(25.44 \%)\end{array}$ & $\begin{array}{l}25 \\
(29.06 \%)\end{array}$ & 0.567 \\
\hline Still-born & $1(0.88 \%)$ & 0 & $\begin{array}{l}\text { Not } \\
\text { done }\end{array}$ \\
\hline $\begin{array}{l}\text { Birth } \\
\text { asphyxia }\end{array}$ & $6(5.26 \%)$ & $9(10.46 \%)$ & 0.167 \\
\hline L.B.W. & $\begin{array}{l}12 \\
(10.53 \%)\end{array}$ & $\begin{array}{l}29 \\
(33.72 \%)\end{array}$ & 0.000 \\
\hline Birth injury & $1(0.88 \%)$ & $1(1.16 \%)$ & 0.841 \\
\hline MAS & $2(1.75 \%)$ & $1(1.16 \%)$ & 0.733 \\
\hline $\begin{array}{l}\text { Neonatal } \\
\text { sepsis }\end{array}$ & 0 & 0 & $\begin{array}{l}\text { Not } \\
\text { done }\end{array}$ \\
\hline $\begin{array}{l}\text { Neonatal } \\
\text { death }\end{array}$ & $3(2.63 \%)$ & 0 & $\begin{array}{l}\text { Not } \\
\text { done }\end{array}$ \\
\hline
\end{tabular}

Table 8: Comparison of birth weight study versus control.

\begin{tabular}{|c|c|c|c|}
\hline Weight & $\begin{array}{l}\text { Study } \\
(\mathrm{n}=114)\end{array}$ & $\begin{array}{l}\text { Control } \\
(\mathrm{n}=86)\end{array}$ & p-value \\
\hline$<2.5 \mathrm{~kg}$ & 12 & 30 & \multirow{4}{*}{0.0003} \\
\hline $2.5-4 \mathrm{~kg}$ & 100 & 56 & \\
\hline$>4 \mathrm{~kg}$ & 2 & 0 & \\
\hline $\begin{array}{l}\text { Mean birth } \\
\text { weight }(\mathrm{kg}) \pm \\
\text { SD }\end{array}$ & $\begin{array}{l}2.88 \pm \\
0.36\end{array}$ & $2.6 \pm 0.34$ & \\
\hline
\end{tabular}

Table 5 shows distribution of cases according to indication of caesarean section. The commonest indication was fetal distress in both study $(35.61 \%)$ and control group $(43.47 \%)$. However, this difference is not statistically significant. Other causes of caesarean section were oligohydramnios, induction failure, Non-progress of labour (NPOL), thick meconium stained liquor and elective caesarean section. Here we can see that incidence of elective caesarean section was more in study group (14/73 or $19.17 \%)$ than control group $(2 / 23$ or $8.7 \%)$ and this difference is found to be statistically significant $(\mathrm{p}<0.05)$.

Table 6 shows maternal complications like shoulder dystocia, prolonged labour, Postpartum haemorrhage (PPH) and cervical tear. However, the differences between study and control group are not statistically significant. There was no incidence of retained placenta, ruptured uterus and maternal mortality in our study.
Table 7 depicts perinatal complications like fetal distress, still-born, birth-asphyxia, LBW, birth injury, Meconium aspiration syndrome (MAS), neonatal death and neonatal sepsis. The occurrence of LBW baby is significantly low in study group $(10.53 \%$ versus $33.72 \%)$

Table 8 shows mean birth weight is more in postdated patients and this data is found to be statistically significant.

\section{DISCUSSION}

Prolonged pregnancy has always been regarded as a highrisk condition as it is associated with increased perinatal morbidity and mortality and instrumental/operative deliveries.

In our study mode of delivery was significantly associated with postdated pregnancy compared with term pregnancy. The number of caesarean sections were more in postdated than in term pregnancy. Similar finding was also observed in a study conducted by Treger et al who tested for occurrence of maternal and fetal complications in low-risk pregnancies beyond 39 weeks involving 36160 patients. ${ }^{16}$ The statistical analysis showed that the number of caesarean section, meconium stained amniotic fluid and NPOL were significantly higher with increasing gestational age. Similar finding was also observed in a study conducted by Luckas et al which compared the outcome of spontaneous labour in uncomplicated term and postdated pregnancy. $^{20}$ Caesarean section was significantly more common in postdated women.

In our study the rate of induction of labour is significantly higher in study group than control. The rate of induction as quoted by various authors was $20-40 \%$. In our study it was $\sim 50 \%$ in postdated pregnancy.

The incidence of caesarean section is more in induction of labour group than spontaneous onset of labour group (63.79\% versus $47.62 \%)$. This finding is similar with a study conducted by Thangaraj et al. ${ }^{21}$ In most of the studies, labour induction at 42 weeks has a higher caesarean section rate compared with spontaneous onset of labour.

The indication of fetal distress for caesarean section in present study is $29 \%$. In other studies like Chaudhari et al it is $21 \%$, Thakur et al it is $10.12 \% .^{22,23}$ In present study none of the indication for caesarean section was statistically significant.

While comparing maternal complications postdated mothers showed a clear cut preponderance for developing shoulder dystocia $(3.51 \%$ versus $0 \%)$ and $\mathrm{PPH}(7.89 \%$ versus $3.49 \%$ ) probably due to increased birth weight of the baby in them. Caughey et al studied 119254 women who delivered at 37 completed weeks and beyond. ${ }^{24}$ They have found that the rates of operative vaginal delivery, $3 \mathrm{rd}$ and 4th degree perineal laceration and chorioamnionitis are increased at or beyond 40 weeks as compared to 39 
weeks of gestation. The rate of $\mathrm{PPH}$, endometritis and caesarean section is increased at 41 weeks. Our study shows a similar trend of result.

We have included different parameters for perinatal outcome in our study like fetal distress, still-birth, birth asphyxia, LBW, birth injury, MAS, neonatal sepsis and neonatal death. The study shows a high incidence of still birth, MAS and neonatal death in study group. Incidence of low birth weight baby is significantly less in study group $(10.53 \%$ versus $33.72 \%)$. It was also seen that the incidence of birth asphyxia and birth injury is less in postdated group probably due to increased rate of caesarean section. Lastly the mean birth weight of postdated delivery is significantly higher in study group.

\section{CONCLUSION}

Any pregnancy that goes beyond 40 weeks of gestation is considered to be high risk. Fetal wellbeing must be assessed and proper management should be done to reduce the rate of perinatal morbidity and mortality. The present observational study confirms that the incidence of induction of labour and caesarean section is significantly higher in postdated group. Although the lower incidence of low birth weight baby in postdate group is an encouraging factor to allow a pregnancy to prolong but simultaneous increased risk of operative deliveries lead us to rethink about the decision. So a policy should be made for induction of labour at 41 weeks of gestation after confirming fetal maturity and wellbeing so that the incidence of maternal and perinatal complications can be brought down to an acceptable level.

\section{Funding: No funding sources}

Conflict of interest: None declared

Ethical approval: The study was approved by the Institutional Ethics Committee

\section{REFERENCES}

1. ACOG Practice Bulletin. Clinical management guidelines for Obstetrics and Gynaecologists. Management of post-term pregnancy. Obstet Gynaecol. 2004;104(3):639-46.

2. Olesen AW, Westergaard JG, Olesen J. Prenatal risk indicators of a prolonged pregnancy- The Danish Birth Cohort 1998-2001. Acta Obstet Gynaecol Scand. 2006;85:11;1338-41.

3. Van der ven AJ, Van Os MA, Kleinrouweler CE. Mid pregnancy cervical length in nulliparous women and its association with post-term delivery and intrapartum caesarean delivery. Am J Perinatol. 2016;33(1):40-6.

4. Oberg AS, Frisell T, Svensson AC. Maternal and fetal genetic contributions to post-term birth; familial clustering in a population -based sample of 475,429 Swedish births. Am J Epidemiol. 2013;177(6):531.
5. Laursen M, Bille C, Olesen AW. Genetic influence on prolonged gestation : a population based Danish twin study. Am J Obstet Gynaecol. 2004;190:489-94.

6. Ayyavoo A, Derraik JG, Hofman PL. Post-term births: are prolonged pregnancies too long? J Pediatr. 2014;164(3):647.

7. American College of Obstetrician and Gynecologists: Management of late-term and postterm pregnancies. Practice Bulletin No.146. 2014. Accessed on 20 July, 2020.

8. Leveno KJ, Quikr JG, Cunninghum FG. Prolonged pregnancy. I. Observations concerning the causes of fetal distress. Am J Obstet Gynecol. 1984;150:465-73.

9. Trimmer KJ, Leveno KJ, Peters MT. Observation on the cause of oligohydramnios in prolonged pregnancy. Am J Obstet Gynecol. 1990;1990:163.

10. Oz AV, Holub B, Mendilcioglu I. Renal artery Doppler investigation of the etiology of oligohydramnios in post term pregnancy. Obstet Gynaecol. 2002;100(4):715-8.

11. Martin JA, Hamilton BE, Osterman MJK. Births: final data for 2013. Natl Vital Stat Rep. 2015;64(1):1-65.

12. Jazayeri A, Tsibris JC, Spellacy WN. Elevated umbilical cord plasma erythropoietin levels in prolonged pregnancies. Obstet Gynecol. 1998;92(1):61-3.

13. Rand L, Robinson JN, Economy KE. Post term induction of labour revisited. Obstet Gynecol. 2000;96(5):779 -83.

14. Campbell MK, Ostbye T, Irgens LM. Post-term birth: risk factors and outcomes in a 10-year cohort of Norwegian births. J Obstet Gynaecol. 1997;89(4):543-8.

15. Alexander JM, McIntire DD, Leveno KJ. Forty weeks and beyond. Pregnancy outcomes by week of gestation. J Obstet Gynecol. 2000;96(2):291-4.

16. Treger M, Hallak M, Silberstein T. Post term pregnancy: should induction of labour be considered before 42 weeks? J Maternal Fetal Med. 2002;11(1):50-3.

17. Eden RD, Seifort LS, Winegar A. Perinatal characteristic of uncomplicated post date pregnancies. Obstet gynaecol. 1987;69:296-9.

18. Materno-fetal committee. Post term pregnancy (committee opinion). SOGC. Clinical practice guidelines. No 15. Society of Obstetrician and Gynaecologist of Canada. 1997. Accessed on 2017.

19. Evidence-based clinical guideline. No 7. Royal College of Obstetrician and Gynaecologists. 2001. Accessed on 20 July, 2020.

20. Luckas M, Buckett W, Alfirevic Z. Comparison of outcomes in uncomplicated term and postterm pregnancy following spontaneous labour. J Pernat Med.1998;26:475.

21. Thangarajah F, Scheufen P, Mallmann P. Induction of labour in late and postterm pregnancies and its impact on maternal and neonatal outcome. Geburstshilfe Frauenheilkd. 2016;76(7):793-8.

22. Chaudhari SN, Bhikane DB, Gupta P. Int J Reprod Contracept Obstet Gynecol. 2017;6(5):2077-82. 
23. Thakur R, Kelkar YV, Shrivastava N. Perinatal risks in postdated pregnancy presented in 29th all India congress. Obstet Gynecol. 1985.

24. Caughy AB, Stotland NE, Wasington AE, Escobar GJ. Maternal complications of pregnancy increase beyond 40 weeks gestation. Am J Obstet Gynecol. 2007;196(2):155e1-e6.
Cite this article as: Karmakar S, Bid S, Maiti TK. A study of post-dated pregnancy with special reference to maternal and perinatal outcome in nulliparous women. Int J Reprod Contracept Obstet Gynecol 2020;9:4574-9. 